written his papers without having read Boole's "Laws of Thought." I knew that he was very anxious that the fact should be known, and I called attention to it. I could not state it as a fact known to me. His own assurance was the only ground $I$ had, or could have, to go upon, and in assigning this it never occurred to me to doubt his statement, or to think that I was suggesting doubts to other.

As regards my half humorons suggestion that an attitude of slight social repression was desirable towards novelties of mere notation-not towards new conceptions or methods-I feel sure that almost every one who has not a private scheme of his own to protect will agree with me. Few things can be more perplexing to students of any subject than to find one author after another making use of a new notation to express old results (I mean no special reference to Mr. MacColl here, who does not seem to me one of the worst offenders in this way). At the time of writing my "Symbolic Logic" I had between twenty and thirty such schemes before me. Some of these, of course, express really distinct conceptions, or effect improvements in procedure, but most of them do not; we find half-a.dozen different signs standing for the same meaning, and half-a-dozen different meanings assigned to the same sign. I cannot but think that much of this confusion would be avoided if the various authors would take the trouble to inquire what had been already written upon their subject. The only "repres-ion" I should like to see introduced consists in the remonstrances of reviewers and students generally against the mere substitution of a new symbol for one which was already in use for expressing precisely the same process or conception. So far from wishing to discourage any attempts to improve on the results of Boole and others, I rejoice to see them, and think that Mr. MacColl himself has done some good work in this way. It would have been better still if he had not disfigured it by a notation which I think makes him regard his results as more original than they really are.

I need not seriously discuss those parts of Mr. MacColl's letter which give his opinion as to the impression which will be produced in other persons by a perusal of my book, and his "impression" that he has "somewhere seen Mr. Venn quoted as holding an opinion very much at variance with " a statement which he misquotes. ${ }^{x}$ (By the way, I heartily agree with his "protest against that spirit of criticism which would offer two or three chipped bricks as a fair srecimen of a house," \&c., and think the chipping of the bricks a happy turn.) The rest of his letter contains criticisms upon my conclusions on a variety of rather intricate speculative questions. Having stated my own views as fully and accurately as I conveniently could only a few weeks ago, in a systematic work, I really must decline to be drawn into repeating them again, in a conden ed form, in the columns of a scientific journal, even if the editor would consent to accept them.

Cambridge, June 12

Telephones in New Zealand, \&c.

OBSERVING your paragraph on this subject in NATURE, vol. xxiv. p. 88, it occurs to me that the following may be of interest :- When iu Wellington and Dunedin, N.Z., at the end of December last, my opinion was asked by the Government Telegraphic officials there upon a pair of ordinary "Edison-Bell Telephones" (not Edison bell-telephones, as they are too frequently called) which they had just received from the United States for purposes of experiment. A careful trial under various conditions showed me that they were very good average instruments of ordinary delicacy, such as I had seen hundreds of previously in England and the States.

With these instruments, however, Dr. Lemon, the Superin. tendent of the Postal and Telegraph Service, was able to converse clearly between Wellington and Napier, over an ordinary land line 232 miles in length, while battery currents were passing over the wires on the same posts.

In New Zealand, Telegraphic communication is, and Telephonic communication will be, entirely in the hands of the Government. In Melbourne the telephone-exchange is worked by a private company, but the erection and maintenance of wires is carried out by the Victorian Government at the annual rate of $5 l$. per sub-

I What I spoke of was "those problems in Probability which Boole justly regarded as the crowning trinmph of his system." What Mr. MacColl puts between inverted commas is that Boole "justly regarded his problems in Probability as the crowning triumph of his system," and challenges me to soy whether or not I agree with Boole's solution of a certain well-known example. This considerably distorts the meaning of what I said. scriber. In Sydney, I regret to say, nothing was being done in this matter. In Honolulu I found (last January) telephoric communication all over the town, but no telegraphs at all. The King of the Sandwich Islands however, Alii Kalakaua, who is shortly expected in England, told me that he greatly needed submarine cables between the various islands. On my return to England I had the pleasure of sending to Sydney materials for a private telephonic line on sugar plantations in the Fiji Islands, and my friend Mr. Frederick Cobb, manager of the Falkland Islands Company, tells me that the line he took out there at my suggestion is a great success.

At Wellington, where the central N.Z. telegraph office is, I was very much struck by the extreme ease with which duplex circuits were worked. Dr. Lemon informed me that it was scarcely necessary to alter the resistances once a week. He showed me a simple little carbon rheostat of his own invention which appeared to answer admirably; it consisted essentially of two pieces of carbon, the closeness of whose contact was regulated by a screw.

On my way home I paid a hurried visit to the central office of the Western Union Telegraph Company in New York (just at the critical time of the absorption by it of the other two companies and the consequent creation of a monopoly), and was greatly surprised to see the extent to which the 16,000 cells in the battery-room were being replaced by Siemens's dynamo. machines. I was told that one of them would "drive" about fifty wires, and was shown a number of plaster-of-paris cylinders, about five inches long and one inch diameter, which were put into circuit to diminish, when necessary, the intensity of the current. It may be remembered that as a rule American lines are less perfectly insulated than ours, and hence require stronger currents.

6 , York Buildings, Weymouth, June I

WM. LANT CARPENTER

\section{Implements at Acton}

Mr. Perceval's letter in NAture, vol, xxiv. p. ror, is an interesting one, but the occurrence of Neolithic implements at and near Acton has been known (if not published) for many years past. In the Pitt-Rivers' collection may be seen Neolithic scrapers and flakes from the Acton district. I have found Neolithic stones in the neighbourhood of Acton and Willesden for many years past; and only a few weeks ago I picked up a beautiful and perfect knife of black flint made from a large flake, five and a half inches long, and one and three quarter inches wide, in the field on the east of Acton Station of the North London Railway. Many of the Neolithic flints from this position are white. A considerable number of Neolithic implements and flakes have at different times been dredged up from the Thames to the West of London, and some of these have been quite recently exhibited. I do not attach imporiance to the quartzite pebble, as pebbles of quartzite are extremely common in the glacial deposits at the North of London, and very common in the gravels of the Thames and its northern tributaries. They also occur in situ at the north of Willesden.

Will Mr. Perceval kindly furnish the heights at the Hammersmith position, and say whether he is positive that the gravel he has in view was dug on the spot, and whether the imple. ments occur there (as his letter implies) in "remarkable abundance"? I have repeatedly examined the low gravels about Hammersmith, Fulham, and Chelea, but with no result. For more than three years I have never missed an opportunity of looking over the low gravels belonging to these places, together with the positions at West Brompton and Kensington, where thousands of tons of gravel have been excavated. My result has been one dubious flake, probably washed down from one of the higher terraces. I however have heard of two Palæolithic implements having been found-one at Kensington and the other at West Brompton-but whether from the local gravel or not I am uncertain

I by no means wish to imply that because I have been unable to find implements in the lower gravels therefore some one else may not have found them. Some one may have been always before me and picked them up, or I may have constantly looked over unproductive patches.

The places mentioned by $\mathrm{Mr}$. Perceval are, it must be remembered, frequently ballasted with gravel brought from a distance by the Thames, by the Grand Junction Canal, and by the Great Western Railway. I know of at least five different localities whence the Acton and Hammersmith gravel is brought, one 